\title{
Reflections of a College Librarian: Looking for Life and Redemption This Side of ARL
}

\author{
William A. Moffett
}

The professional status of the college librarian has declined in ALA and ACRL as the prestige and importance of research-centered universities has grown. Current enrollment trends in higher education portend a special threat for colleges, adding yet another dimension to the problems-real and perceived-inherent in smaller institutions. Professional librarianship's bias in favor of large institutions reflects a lack of understanding of the challenges and rewards of college librarianship.

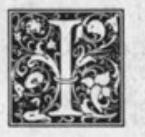

have been asked to speak on myths and realities: the college perspective. It doesn't sound like the kind of subject that lends itself to oratory, does it? I regret that. Just for a change, it would be interesting to have a library conference talk that would rouse us. Along with all our bland earnestness at library gatherings, I'd like a good peroration occasionally, wouldn't you? A stirring exhortation! Something memorable!

But there are perils in that. I should have learned that in the little high school I attended in the bayou country of southern Mississippi. That was back in the days when there were frequent student assemblies, and it was an accepted thing to bring in the local ministers and other public figures of the village to give us inspirational talks. I recall that we made it pretty tough for the speakers. You might say that we defied them to inspire us. We were bored. We were inattentive. We dozed. We worked math problems. I'll never forget one desperate clergyman who apparently decided we would remember his message. At the climactic moment, he drew from his vest pocket a wooden object and blew what was indisputably the loudest duck call ever heard in that room. As we sat there stunned, transfixed, he rendered his words of wisdom. And his talk was remembered. For years we laughed about that crazy preacher and his duck call. None of us, regrettably, harbored the slightest recollection of what it was he had so earnestly wished to leave indelibly printed on our young minds.

And it is true that a few years ago in an address to the plenary session of the ACRL at an ALA meeting in Chicago, I determined that a crucial part of my talk was written on a tombstone. So I lugged the darn thing all the way up to the podium, and for years I have been encountering people at these conferences who come up to me and say: "Hey, weren't you the guy

William A. Moffett is director of libraries, Oberlin College Library, Oberlin, Ohio 44074. This paper was presented at the ACRL Third National Conference, April 4-7, 1984, Seattle, Washington. The author would like to acknowledge with gratitude the comments and suggestions of many colleagues, especially Edwin Bronner (Haverford), Evan Farber (Earlham), Michael Freeman (Wooster), Charles Maurer (Denison), Christopher McKee (Grinnell), Mahlon Peterson (St. Lawrence), Herbert Safford (Muskingum), and Bill Miller (Michigan State). 
with the tombstone?" And I say, "Yep!" And then they usually say, "Um, hmm." Do I ask them if they remember the point I was trying to make? Oh, no! I know better. Being memorable has its perils.

Bearing that in mind, I want to talk a bit about the decline of the status of the college library in ALA and ACRL. I want to talk some about the crisis of higher education and the special dilemma it holds for colleges. And I want to talk about the implications of both for college librarians.

The "college perspective"? There are in fact lots of college perspectives, but nothing that could be said to represent all colleges, or even colleges generally, for there are so many and they are so varied in size, type, and purpose. That variety constantly undermines the effectiveness of the College Libraries Section-a section which in terms of clout is, I'm afraid, one of the weakest in ACRL. The only thing we seem to agree on is that if we abolished the section today, someone would try to resurrect it tomorrow. There has to be a college libraries section; it is the oldestindeed, ACRL itself grew out of the College Library Section of ALA.

But if one looks at the membership list to see who's on it and what libraries they work in, one soon discovers a range from small institutions such as the College of the Desert in Twentynine Palms, California (one of my favorite place-names), with fewer than 50,000 volumes, to Wesleyan in Connecticut, which is fast approaching the million mark. There are lots of colleges in between. They are private; they are state-supported. They are churchaffiliated; they are nonsectarian. Some think of themselves as traditional liberal arts colleges; others, following the lead of the community colleges-which, of course, have their own section-are heavily committed to individualized, consumer-oriented education. Some are parts of urban university complexes; others stand alone in the vastness of the prairie. They just don't hang together neatly as a group. About the only thing they have in common is that when you compare them with the top hundred or so universities in ARL (and the next phalanx of large institutions whose librarians apparently yearn to be in that select group), the purely undergraduate colleges-let's face it-are small.

Much of what I want to say has to do with the implications of that last statement. What are the effects-real and perceived-of being part of a small academic institution in America?

\section{WHO ARE THE "COLLEGES"?}

For the purposes of this address we have to agree on some useful generalization that will serve as the idea of what is meant by the term college. In the absence of a conventional definition that embraces the variety of institutions I have noted, I had thought that we could use a definition that emerged from the statistical delimiters of a recent survey-indeed, one of the first fairly comprehensive studies of college libraries to appear in our literature in many years. ${ }^{1}$ In his report, Dennis Reynolds focused on the approximately three hundred academic libraries listed in The American Library Directory supporting institutions in which the highest degree granted was the baccalaureate, where the enrollment was between 500 and 2,000 students, and whose shelves contained between 65,000 and 250,000 volumes. For our purposes, however, those delimiters are not entirely suitable, for they exclude a number of well-established, mostly undergraduate institutions in which a lot of us work. (Indeed, I should observe that it does exclude my own institution, for example, because we have about 2,750 undergraduates, counting those in the Conservatory, many of whom take double degrees in the College of Arts and Sciences, and our library has around 900,000 volumes-if one counts all those thousands of books too brittle to use.) Perhaps it would be better to think in terms of mostly undergraduate institutions with less than 4,000 students and with libraries of no more than one million volumes, while remembering that there are many institutions well below those limits.

I should also say at the outset that a key frame of reference for me-but not an exclusive one-is the concept of the liberal arts college: that undergraduate institution which offers an education both se- 
quential and cumulative, theoretical yet practical, specific and interrelated; which seeks to nourish the mind without neglecting the interests of the whole person. Put differently, I have in mind the kind of institution that accepts the assertion advanced by one of Oberlin's most articulate sons, Robert Maynard Hutchins, who insisted that the aim of higher education should be to produce men and women of goodness and wisdom. ${ }^{2}$ In short, I mean those institutions deliberately attempting to serve as a bit of leaven in the lump of Western civilization. ${ }^{3}$

Back to myths and realities. It is a fact that through the nineteenth century, when the traditional liberal arts colleges were still ascendant, the term college simply meant "academic." The word was used indiscriminately for all institutions of higher learning well into this century, including those now largish institutions whose constituents would be somewhat offended if one misspoke and called them colleges today. With the rise of the modern university in the early part of this century, and the flowering-if that's the right word-of the multiversity after World War II, things were different. The term college had acquired a more restricted meaning; it now referred to a subset of higher education, the most obvious characteristic of which was that its individual members were comparatively small and insignificant.

\section{DECLINE OF THE STATUS OF THE COLLEGE LIBRARY IN ALA AND ACRL}

That development was reflected, of course, in the history of our own professional associations. When the American Library Association was founded, its first president was an academic librarian-a college librarian, if you will-Justin Winsor of Harvard. Yet almost from the first there was grumbling from the academics about the association's orientation toward the public sector, and that dissatisfaction-which expressed itself most pointedly by the threat of holding separate meetings such as the very one we're having in Seattle-led to the formation of the
College Library Section in 1890 , not officially recognized by ALA until 1900 .

Perhaps I could digress here to remind you that only a fifth of ALA presidents have been academic librarians. For a time it appeared to have been ordained that a college librarian was to be made president at thirty-year intervals. Thus, William Isaac Fletcher of Amherst so served in 1891-92; and exactly three decades later, it was the turn of one of my esteemed predecessors at Oberlin, Azariah Root; and in another thirty years it was the librarian of Mt. Holyoke, Flora Belle Ludington.

But the thirty-year cycle has been broken. Indeed, as the mystical year of 1981-82 approached, and passed, it seemed hard to imagine ALA ever again electing a college librarian to its presidency. For that matter, fifteen years have passed since ALA has had a president who was indisputably an academic librarian, if you reckon Russell Shank as having come from the Smithsonian. (It is probably significant that during the past fifteen years seven ALA presidents have come from the field of library education.)

To return to my narrative, it is fair to say that throughout the early years academic librarians' loyalties in ALA turned to the College Library Section, which itself went through several changes. First of all, its name was changed to the College and Reference Libraries Section in recognition of the affinity with the reference specialists of the major public libraries. Subsequently it was called an association instead of section and elevated to divisional standing. In the reorganization of 1938, it set up five distinct subdivisions: one for junior colleges (eventually to be called community colleges), one for reference librarians in the large public libraries, one for librarians of teacher-training institutions, and, formally splitting the universities from the colleges for the first time, one for each of those categories. Actually, only a few years earlier some of the directors of the large institutions had taken the first steps that were to lead to the formation of the Association of Research Libraries-and that, as nothing before, marked a refinement of what was meant by college. Fifty- 
three percent of the libraries represented among the original membership of the College Library Section became charter members of the new ARL fraternity. ${ }^{4}$

In 1939 when the new associational journal $(C \mathcal{E} R L)$ appeared, the $R$ no longer stood for reference but for research. As A. F. Kuhlman explained in the first issue, three of the association's sections were for "colleges," and "as for the other two [sections], in the strict sense of the word, 'university' stands for research. ${ }^{\prime 5}$

Eventually the association, too, changed its name to the Association of College and Research Libraries, thus reenforcing the sense that college and university libraries were two quite different kinds of enterprises. Indeed, the college library had plainly fallen to a very secondary status in the profession, and as the modern university came increasingly to represent American higher education, the college librarian's role in the association was predictably much reduced. In a way that diminution of status is symbolized, no doubt inadvertently, by the very arrangement of the theme addresses at this conference: leading off with the university perspective and letting the college librarian tag along at the end, like a caboose.

\section{THE CRISIS \\ IN HIGHER EDUCATION}

Occasionally at this conference we've heard some allusions to the present crisis in higher education. Actually, it has always been possible to describe American higher education in any decade as being in a state of crisis. That's the way educational pundits talk. But as one gloomy Carnegie report after another has described what the future seems to hold in store for us, crisis does not seem an inappropriate word. ${ }^{6}$

In part, I suppose, it represents the legacy of a loss of confidence in all our institutions that young people have felt beginning with the trauma of Vietnam and the troubles of the sixties. Doubtless, part of it is economic: the contracted jobs market, the overall decline in growth that became acutely felt in the seventies and continues, in higher education, at least, today. In part it must reflect a dissatisfaction with the alienation, depersonalization, and shallowness that is commonplace in our colleges and universities, as well as throughout our society.

Sometimes the very reading of the various reports of anguish and alarm emanating from academia conjures up for me a frightful phantasmagoria, a circus of the macabre:

In the center of the arena lumber those ponderous, overgrown educational behemoths, fattened on government grants, showing a growing appetite for research contracts with multinational corporations, recognizable by their massive institutional services, their global ambitions, and their blinkered faculty attendants (themselves preoccupied with personal research and individual aggrandizement, innocent of a shared purpose, who mill about, disheartened, while teams of bureaucratic mahouts try vainly to gain control of the massive beasts) and hectored all the while by people with sharp-pointed sticks marked GOVERNMENT REGULATIONS, RETRENCHMENT, COLLECTIVE BARGAINING, COST EFFECTIVENESS, and COMMERCIALIZED ATHLETICS. For all their size, there is about these Gargantuas a look of sameness and conformity that is curiously disquieting.

From seemingly everywhere throngs of community colleges-looking for all the world like fast-food vendors-hawk their wares through the assembled spectators. They already account for more than 50 percent of the postsecondary students in the country, but still hustle in order to expand their markets.

Here and there someone has set up a stand to tout the latest faddish panacea. COMPETENCY-BASED EDUCATION reads one old banner; LIFE-LONG LEARNING proclaims another. Neither is attracting great enthusiasm.

Passing over a variety of other institutional creatures on the floor of the arena, one is conscious of some frightened figures huddled in clusters around the periphery, eyeing one another somewhat suspiciously. They're the four-year colleges. They've just been reminded by the public address system for the umpteenth time that the pool of available freshmen is still shrinking and there will not be nearly enough to go around. Some of them are not going to 
survive! Frantically a few attempt unconvincingly to disguise themselves as universities by expanding their course offerings. Others start following the community college vendors into the crowd. Some are nervously studying their mission statements, and here and there you see one scanning the yellow pages in search of a good public relations firm to help polish its image. From time to time you find one slumped in disbelief, paralyzed by uncertainty. An air of anxiety and sadness hangs over the whole scene.

It's not a pretty picture. Is it myth or reality?

Well, the plain truth is that there are serious challenges all of us face in higher education, and the conventional wisdom is that smaller institutions are in trouble.

\section{SPECIAL IMPLICATIONS FOR COLLEGES}

With fewer students coming from the secondary schools, colleges have been preoccupied with survival strategies. But if you cut back your curricula and scale down your programs, your institution risks making itself less attractive to your traditional clientele. If you try to maintain your student enrollment by lowering admissions standards, or by endeavoring to attract new students by changing the mission of the college, you can lose in another way. There are many other factors that exacerbate the enrollment plight of the small private colleges. For example, because the education of secondary school teachers and guidance counselors has passed almost entirely to large public universities in every state, there is decreasing awareness in the schools of what it is that smaller, and often private, institutions have to offer, creating yet another twist to the colleges' admissions problem.

In any event, it seems, the future of the smaller institutions may be in doubt, if not in actual jeopardy. That's an eventuality the large institutions apparently do not face. There one may fret about the effects on individuals of retrenchment and budget reallocations-and even the loss here and there of a program or a department, including some of those superfluous schools of library science. One may, of course, become rightly anxious about the quality and direction of the overall educational program. But the question of the long-term survival of the university does not hang like a pall over the campus.

Being small in American academia means living with that terminal question.

Being small in American academia means being ineligible for many research grants, being nosed aside from the trough of many federal and state subsidies. ${ }^{8}$

Being small means limited resources for capital improvements; it means being hard-pressed to buy the instruments essential for first-class instruction in analytic chemistry.

Being small in academia means having difficulty attracting and sustaining the ablest teachers and librarians and providing adequate opportunities for personal development for both faculty and staff throughout their careers. As someone reminded me recently, even those colleges that succeed in creating stimulating environments in which college students may grow and develop for four years of postadolescence may not be able to provide the most suitable places for adults to grow and flourish for forty years after attaining adulthood.

Being small in academia often means a lack of social and cultural diversity. Many colleges were established in little towns that are now off the beaten track. For residents of some such locations, one might not be able to find a decent Chinese restaurant within an hour's drive! Sad to say, some people dwell in towns in which the aroma of a freshly baked bagel has never brought joy to the human nostril!

But underlying it all, being small in American academia means having to endure the nagging sense of being in the minors. In our country size confers authority, prestige, legitimacy: the big time! the major leagues! the super bowl!

Nothing illustrates this so well perhaps as the appearance not long ago of something called The Gourman Report (Los Angeles: National Education Standards, 1983), a two-volume work purporting to be a guide to the quality of undergraduate and graduate education in the United States and abroad. You may have seen an article about it in the February 15, 1984, is- 
sue of the Chronicle of Higher Education. For that matter you may have seen something in your local newspaper because it triggered wide reaction by educators, ranging from skepticism to outrage.

Aside from a highly suspect system of consecutively ranking about a thousand undergraduate institutions, for example, it characterized more than 80 percent of overall academic programs in the country as being no better than "adequate" or "marginal," and of the 16 percent that were "acceptable plus" or better, it reckoned only 3.5 percent as "strong." Fouryear liberal arts colleges invariably fell within the merely "adequate" or "marginal" categories, including the country's best-and private colleges generally ranked poorer than publicly supported ones.

The reason is not hard to discover, although Gourman is rather vague about his methods. All his indicators are utterly and consistently skewed by one crucial factor: size.

The Gourman Report has been labeled a fraud, and no one I know takes it seriously. Loren Pope, director of the College Placement Bureau, is quoted as calling it a "phony thing" and asserting that "anyone who would rank big institutions like Michigan [which ranked very high] over institutions like Swarthmore, Reed, and Carleton Colleges for undergraduate programs simply has no idea what he is doing. For undergraduates, the big universities are a gyp."

The Gourman Report is interesting, however, because what it asserts in print-and ostensibly on the basis of objectivity-is what many Americans apparently assume: bigger means better. It underscores just one more handicap the colleges face in their struggle for survival, and one the colleges can do nothing about.

\section{THE BIAS \\ AGAINST "SMALL" IN ACADEMIC LIBRARIANSHIP}

Academic librarianship is by no means immune to this bias. Indeed, one can argue that the effect is both pervasive and pernicious.

The final discontinuation of funds for Ti- tle II-A, the federal government's assistance to college libraries, comes to mind as the most obvious expression of a belief that the well-being of smaller academic libraries is unimportant.

Of much greater consequence, however, are the effects of the bias on the assumptions and practices of the members of the library community. For example, our library schools, as has been pointed out, ${ }^{10}$ have made little effort to prepare their graduates for reference work and collection development in college, as opposed to university, libraries, where the function is different in direct proportion to size and mission, a point on which the speakers in our second theme session concurred.

Our library literature, dominated by editors and writers associated with the concerns of large institutions, has very little to say about college libraries, a discovery Bill Miller and Stephen Rockwood made when they began to put together their book on college librarianship a few years ago. ${ }^{11}$

Moreover, assistance to the profession by library agencies-such as the management internships sponsored by the Council on Library Resources-almost invariably tilts to the very large institutions. We cannot even justify such a tilt by calling it a "trickle down" approach, since no one seriously thinks that the benefits to university libraries from such programs ever do trickle down to the colleges; there's certainly no evidence that they do.

Furthermore, a single anecdote may suggest how the bias in favor of size can operate within ACRL's executive office. One of the early and continuing advantages of ARL to its member-directors has been the sharing of basic comparative management data in a timely fashion. For the non-ARL libraries, the cumulated HEGIS statistics-in the days when they appeared at all-tended to be out-of-date and misleading. The ACRL subsequently undertook to collect and distribute data on behalf of the non-ARL members, but not for all dues-paying institutions. Where was the cutoff point drawn? Why, at the line separating institutions that grant doctorates and the rest of us who do not. Col- 
lege library administrators, whose need for up-to-date, accurate, comparable figures is no less pressing, have always had to write back and forth to one another, rely on state cumulations when they existed, or join in small data-sharing cooperatives, such as those voluntarily and unofficially organized by Dennis Ribbens of Lawrence and Arthur Monke of Bowdoin.

\section{PROFESSIONALISM}

The triumph of professionalism in academic librarianship reinforces the bias. It is possible to construct a continuum of our ACRL membership at one end of which there are those academic librarians who tend to see themselves as professional librarians employed in academia; and at the other, those who tend to regard themselves as academics working in libraries. That is, professional specialists, on the one hand, whose first loyalties are to the values of the guild; and on the other, generalists whose professional skills are clearly subordinate to the educational function to which they are committed. By such a continuum, might we not be describing the difference-or at least the different tendency-that characterizes university and college librarians?

One can easily overstate the case, but it seems incontrovertible that in the large academic library, specialization and professionalism can lead individuals to think of the library and librarianship as ends in themselves. In smaller institutions it is less likely that librarians will lose sight of the fact that our mission is really the promotion of learning, not libraries.

The other day I came across an old article by Jerrold Orne (written, I think, to explain why participatory management would not work) in which he described the irresistible process, driven by automation, which was transforming librarians into specialists (especially directors and departmental heads), ${ }^{12}$ a trend we do see in research libraries. But I found myself contrasting this trend with the actual experience of the college librarian who is the very epitome of the generalist. As Charles Maurer recently demonstrated, the successful head of the smaller academic library still has to be able "to do everything, and to do it at the same time."13
In such a library-even with pressing decisions to be made about the judicious application of computer technology (decisions that were not commonplace in 1951) - the essential qualities needed by the librarian in a college environment are even now those that Louis Round Wilson enumerated thirty-three years ago as traits desirable in the director of a research library: high intelligence, fine personality, wide educational interests, an understanding of how the library can contribute to the advancement of educational programs, imagination, sound common sense, intellectual drive, experienced and capable administrative ability, capacity for dynamic leadership, scholarship, an understanding of the spirit and purpose of research, a broad, humanistic outlook on books and all that enriches life. ${ }^{14}$ There's not a word in Round's list about specialization; not a line that smacks of narrow professionalism!

Compare that list with the hallmarks of professional success recognized in this association: credentials; expertise within fairly circumscribed fields of technical specialization; visibility on committees and councils; authorship of arcane publications; membership on prestigious boards; strings of consultantships-all of which we readily associate with career advancement in the large institutions, and much less frequently with advancement in the small.

Visibility on ALA and ACRL committees requires-among other thingsassured funding for repeated travel to national professional meetings, something most small college librarians simply don't have or may not think is a leading priority. Indeed, it is unclear whether the reason we don't see much of the college librarians at ALA meetings is due to their lack of funds, or because college librarians find gratification in their work and are not driven to seek fulfillment in so-called professional growth. ${ }^{15}$

Be that as it may, size of library (and the professionalism and specialization associated with it) does determine the conventional definition for accomplishment in this business. Take a look at a recent issue of $C \mathcal{E} R L$, for example, where you will find this assertion confirmed in a study de- 
scribing the profile of the "successful" librarian: the probability is high, it says, that he or she works in a large academic library, and more than likely an ARL library at that. ${ }^{16}$

Being small in academia-it may be inferred-means being unsuccessful.

The pernicious effects of the bias I have described operate within the very precincts of the smaller institutions themselves. Evan Farber pointed this out a decade ago in "College Librarians and the University-Librarian Syndrome," a paper in which he discussed the pattern of attitudes that may ultimately cause college faculty, administrators, and even college librarians themselves to think of their own libraries in terms of university librariesand then to imitate university practices, attitudes, and objectives, often with very detrimental results. ${ }^{17}$ For faculty and librarians essentially serving undergraduates, the model of library services driven by research (the model articulated by Paul Olum in the second of our theme sessions ${ }^{18}$ and the model with which college faculty and librarians become familiar during their own graduate school experiences) is an unreliable guide. It is the operation of that syndrome, Farber argued, which largely explains why college faculty display a lack of confidence in their own librarians as colleagues, why they often neglect the importance of insuring that their students are taught how to use the library intelligently and independently, and why administrators are often more concerned about whether the library's budget is well managed than whether their students are deriving much benefit from it.

Being small in academia, then, does not mean you escape the larger institutional mind-set even when you're miles from the beast.

\section{REFORM AND RENEWAL}

As a result of such inherent difficulties, can there be any surprise that the smaller college library often fails to attract and retain the most appropriate personnel? Is there any wonder that the prospect of life in the minors can foster a set of selffulfilling, low expectations? I rediscovered this reality during the past year while serving as a consultant to some midwestern colleges searching for head librarians. The opportunities for challenging and highly gratifying career advancement were clearly there; the number of good applicants was abysmally low. Why? It was as if smaller institutions had simply ceased to be attractive.

If colleges are going to survive, if they're going to prosper, I believe that they're going to have to be able to recruit good people for their libraries who understand the difference between the function of the research library and the purpose of the teaching library. One of my personal hopes is that the Great Lakes College Association (and perhaps other college consortia) can be persuaded to offer internships in college library administration, much like those for prospective managers of university libraries offered by the Council on Library Resources-and more recently the residencies developed by the University of Michigan. ${ }^{19}$ By doing so we may be able to compensate for the lack of a recognizable career ladder for college library directors and perhaps counter some of that bias which discourages good people from seriously considering careers in smaller institutions.

That is important because the wellbeing of our colleges is important. It is so, first of all, because of the contribution to American life they have been making all along. Let me cite but a single statistic, one whose significance may not be well understood. If one ranks all colleges and universities by the percentage of their baccalaureate graduates who go on to obtain $\mathrm{Ph}$.D.'s, one finds that seven of the top eleven are independent liberal arts colleges. ${ }^{20}$ Such institutions have been making a contribution to American life and letters out of proportion to their size.

But we need not belabor that point. The well-being of colleges may be even more important for what they may yet become.

For with all the talk of the disintegration of American higher education, and the stultification for undergraduates, especially, in large institutions, it is interesting to find so many thoughtful writers turning once again to the smaller institutions as a possible source of reform and renewal for postsecondary education generally. The 
liberal arts colleges, the argument runs, are less scarred by the student unrest of the late sixties, less dependent on government, less compromised by research contracts with the private sector, less fragmented, less captive of the false gods of professionalism, more responsive to leadership, more open to innovation, better able to confront ethical questions. The classic conservative exponent of this hope was undoubtedly Russell Kirk, but one finds it, too, in the work of Alain Touraine, in some of the later work of David Riesman, and in the recommendations of the Carnegie Foundation-with its emphasis on the importance of colleges with a sense of mission, an identity, a separate and discernible character. ${ }^{21}$

And one finds a particularly useful expression of it in Warren Martin's book $A$ College of Character. Martin defines the essence of character as "disciplined, evident, enduring commitment to principles, usually to goals and purposes seen as moral or ethical, and expressed institutionally." And it is this kind of institution, he argues, not the multiversity, not the miniversity, not the university, that is best able to set the mark for the kind of leadership necessary for fundamental educational reform. ${ }^{2}$

It is not just an ideal or an abstraction. There are colleges of character, and they do serve as models of reform. I commend to you Thomas Cottle's loving evocation of one such place, a Quaker college where a commitment to interactive teaching and to the examined life-not quantifiable education-provides the power that infuses its campus. At Earlham, he wrote in his book College-Reward and Betrayal, devotion to students means helping young people to become more flexible in classes, less hostile toward imaginative experiences; it means postponing consulting jobs and delaying research at times in order to leave one's door open, to talk, to comment often and in depth on student papers; to return in the autumn or in a summer preterm session with new plans, recharged enthusiasm, and endless temerity.

Nor is the chemistry that makes Earlham effective confined to the teaching faculty. It includes, Cottle writes, the "kindness of a librarian" whose concern for students convinces him that a library must be a place for students not only to do research-which he teaches them how to do-but also to browse and nap and dream. "The man whose task it is to oversee this genuinely spiritual center is a part of the lives of students." 23

For those of us in this room who are familiar with that particular librarian's efforts to foster close collaboration between teachers and librarians, it was especially interesting to hear Gresham Riley's appreciative statements about the role of the academic librarian in the small college. ${ }^{24}$ We know how he came by that understanding, for Evan Farber's work at Earlham has been a source of inspiration to many others throughout the country, and not merely in small institutions, either, as many of you can doubtless attest.

\section{APOTHEOSIS}

Is there life this side of ARL? There certainly is at Earlham. And elsewhere. Hear this testimony from the librarian of a small college located near the very center of this country; it is from a letter I received within the past few weeks.

Why do I like being a college librarian? Most importantly, I am aware that my being here has made a real difference for the college. I can see the good things that have happened because of my leadership. I know that they probably would not have taken place if I hadn't had the chance to invest my talents here and in the way I have. Moreover, I know that I am directing the library, not just presiding over it. In short, I have a genuine and a realistic sense of accomplishment.

I have had an opportunity to construct a library building that is the envy of my peers who have seen it. In the process I had a chance to work with, and to become the friend of, one of the most exciting client-oriented architects at work today. My position here is not so remotely managerial that I do not get to put a substantial share of my effort into collection building; although I have a full-time acquisitions librarian I hold that-after providing strong leadership and able management-collection building is the library director's primary responsibility, one upon which all else hangs.

Our library staff is big enough to do its job, but small enough for me to know every member personally and usually to have some conversation with each person every day. We have been able to recruit and to retain the ablest library 
staff I have ever encountered; there is not one weak link in the whole chain; and I will pit them person-Sor-person against any library staff in the country for ability, commitment, enthusiasm, and energy. I have only to travel sixty miles down the road to the University to see a library staffed by crabby, burned-out librarians, laboring on such a tiny part of the mountain as to have little concept of the whole. They stand in contrast to the eager, highly motivated people who staff our college library and seem to have one hell of a good time doing it.

While my job has been demanding, it has not been so absolutely time-consuming that I have been unable to remain active as a working scholar in my academic specialty. Last summer and fall I was able to contribute chapters for two collective volumes as well as continue work on a major book. My spouse and I have a busy social life with a circle of faculty colleagues who are intellectually stimulating and thoroughly cosmopolitan.

Nor has my role been confined within the walls of the library. I have served on several faculty/student committees-of which my long time favorite has been Art Acquisitions, the policy-making body for the College's permanent art collection.

Finally, in purely material terms, I think the financial rewards of my position have been competitive with those I would have received in a large research library. Probably they have been even greater, if one adjusts my generous salary against the higher cost of living in a major university location.

"I have friends who are executives in ARL libraries," the letter concludes. "I am not envious of them."

For this librarian, life in the academic minor leagues, one sees, is both more and less than what it's cracked up to be.

\section{MAKING ONE'S CAREER COUNT}

I said that I did not have a ringing per- oration with which to conclude, and I do not. But since I already have a reputation for bringing you messages engraved on stone, at least you won't be startled if in closing I do that again. This time, at least, I don't have the stone with me. It sits-or at least it did when I saw it many years agoon the other side of this continent, as part of a monument on the battery overlooking the harbor of Charleston, South Carolina. It is, as I recall, an unremarkable monument, but somehow its words have stayed with me over the decades. They say: Count Them Happy Who for Their Faith and Courage Have Endured a Great Fight.

In our time America's colleges are quietly engaged in a great, a momentous struggle. Far more than their own survival is at stake. It is their mission to produce women and men of goodness and wisdom. The nation, the world, needs them.

Liberal arts colleges may no longer prevail, but they do endure. In not all of them will their librarians attain the full potential of the role I have described here in an admittedly idealized way. Certainly, that potential is not often enough understood by their own faculty and administrative colleagues, and sometimes not by librarians themselves. For those who do understand, and especially those who bear their part of the struggle in those purposeful "colleges of character," there is a special satisfaction that comes in knowing that the investment of their time, their personal talents, their energies, and their professional skills counts for something.

And so they soldier on. The least that their colleagues in the profession at large can do is to give them some understanding and cheer them on!

\section{REFERENCES AND NOTES}

1. Dennis Reynolds, "A Survey of Libraries in American Four-year Colleges," in College Librarianship, eds. William Miller and D. Stephen Rockwood (Metuchen, N.J.: Scarecrow, 1981), p.7-29. For other useful discussions of the types of colleges and their roles, see Algo D. Henderson and Jean Glidden Henderson, Higher Education in America (San Francisco: Jossey-Bass, 1979), p.28-39; David G. Winter, David G. McClelland, and Abigail T. Stewart, A New Case for the Liberal Arts: Assessing Institutional Goals and Student Development (San Francisco: Jossey-Bass, 1981), p.151-57.

2. Robert Maynard Hutchins, The Higher Learning in America (New Haven: Yale Univ. Pr., 1936).

3. To borrow a phrase from Russell Kirk, Decadence and Renewal in Higher Learning: An Episodic History of the American University and College since 1953 (South Bend, Ind.: Gateway Editions, 1978), p.xvii. 
4. One of the most convenient short accounts of association development is that by the late W. Carl Jackson, "The National Organizations-ALA, ARL, ACRL: Meeting Academic and Research Librarians' Needs?" in Academic Librarianship: Yesterday, Today and Tomorrow, ed. Robert Stueart (New York: Neal-Schuman, 1982), p.207-30.

5. Introduction to the initial issue, College \& Research Libraries 1:10 (Dec. 1939).

6. Sidney Hook, Paul Kurtz, Miro Todorovich, eds., The Idea of a Modern University (Buffalo, N.Y.: Prometheus Books, 1974); Alain Touraine, The Academic System in American Society, Carnegie Commission on Higher Education series (New York: McGraw-Hill, 1974); The Carnegie Foundation for the Advancement of Teaching, More than Survival: Prospects for Higher Learning: An Episodic History of the American University and College since 1953 (South Bend, Ind.: Gateway Editions, 1978); Kenneth H. Ashworth, American Higher Education in Decline (College Station: Texas A \& M Univ. Pr., 1979); The Carnegie Council on Policy Studies in Higher Education, Three Thousand Futures: The Next Twenty Years for Higher Education (San Francisco: Jossey-Bass, 1980); Ernest A. Lyndon, "Reexamining the Role of the University: A Crisis of Purpose," Change 15:18-23, 53 (Oct. 1983); George B. Weathersby, "Our Fading State Colleges: Have They Lost Their Vitality and Mission?" Change 16:18-23, 49 (Jan./Feb. 1984); Sherman Jones, "Difficult Times for Private Black Colleges," Change 16:24-31 (Mar. 1984); Dorrit Cowan, "The Expanding Conflict: Society's Demands/Academic Independence," Change 16:34ff. (Apr. 1984). Perhaps the most recent comprehensive review was volume 35 of the Proceedings of the Academy of Political Science, published as The Crisis in Higher Education, ed. by Joseph Froomkin (New York: Academy of Political Science, 1983).

7. David W. Breneman, "The Coming Enrollment Crisis: Focusing on the Figures," Change 15:14-19 (Mar. 1983); Stephen P. Dresch, "College Enrollment," in The Crisis in Higher Education, p.108-18.

8. For example, despite general increases in the budget of the National Science Foundation, that agency has apparently written off liberal arts colleges and other institutions lacking a graduate program. The Department of Education refuses to fund foreign-language programs except in the large universities. The revolving door of personnel appointments between the universities and these government agencies, moreover, seems likely to reinforce the attention being given to the interests of the former. Insofar as large also means public, the bias is reflected on the federal level in the recent cuts in financial aid to students, which are especially injurious to private education. At the same time, on the state level public institutions are becoming much more aggressive, and successful, in going after foundation support once regarded as the special source of help for institutions lacking state revenues. There is a special irony here. Being small and first-class in academia usually requires efficient and prudent fiscal management. State-supported higher education, while almost invariably more expensive and less efficient (running perhaps 40 percent higher in costs per student), reacts to budget cuts not necessarily by belt-tightening and greater efficiencies, but by raiding the revenue sources of the private institutions.

9. Beverly T. Watkins, "New Edition of a Guide to College's Quality Gets a Mixed Response," Chronicle of Higher Education (Feb. 15, 1984), p.12-13; Susan Goldberg, "Michigan Colleges Rankle at Rankings: Educators Criticize Guidebook, Author," Detroit Free Press (Mar. 5, 1984).

10. Evan Farber, "College Librarians and the University-Librarian Syndrome," in The Academic Library: Essays in Honor of Guy R. Lyle, eds. Evan Farber and Ruth Walling (Metuchen, N.J.: Scarecrow, 1974), p. 20.

11. Miller and Rockwood, College Librarianship, p.1.

12. Jerrold Orne, "Future Academic Library Administration-Whither and Whether," in The Academic Library, p.82-95.

13. Charles Maurer, "Close Encounters of Diverse Kinds," in Miller and Rockwood, p.97-105.

14. Louis Round Wilson, "What Type Research Librarian?" in Reader in the Academic Library, ed. Michael M. Reynolds (Washington: Microcard Editions, 1971), p.219-22.

15. The more crucial problem for the staff of the smaller academic library is not the lack of travel funds so much as it is the lack of enough professionals to constitute the critical mass necessary for healthy dialogue and mutual in-house support on a daily basis.

16. John N. Olsgaard, "Characteristics of 'Success' among Academic Librarians," College \& Research Libraries 45:5-13 (Jan. 1984).

17. Farber, "College Librarians and the University-Librarian Syndrome," in The Academic Library, p.12-23.

18. The theme paper of Paul Olum can be found on p.362-66 of this issue of CERL.

19. Richard M. Dougherty and Wendy P. Lougee, "Research Library Residencies: A New Model for Professional Development," Library Journal 108:1322-24 (July 1983).

20. In an unpublished study of the baccalaureate origins of doctorate recipients, Carol Fuller deter- 
mined that the top twenty-four most productive institutions for $1960-80$, in order of rate of productivity, are: California Institute of Technology, MTT, Reed College, Swarthmore, University of Chicago, Haverford, Oberlin, Amherst, Pomona, Carleton, Wabash, Rice, Princeton, Case Western Reserve, Grinnell, Cooper Union, Harvard, Wooster, Wesleyan, Davidson, Hamilton, Wheaton (III.), Williams, and Bowdoin. A comprehensive study of the overall performance of private institutions is summarized in Alfred E. Hall, "Starting at the Beginning: The Baccalaureate Origins of Doctorate Recipients, 1920-1980," Change 16:40-43 (Apr. 1984).

21. Kirk, Decadence and Renewal, p.293-301; Touraine, The Academic System, p.261-62; Gerald Grand and David Riesman, The Perpetual Dream: Reform and Experiment in the American College (Chicago: Univ. of Chicago Pr., 1978); Carnegie Foundation, More Than Survival, p.6-7.

22. Warren Bryan Martin, A College of Character (San Francisco; Jossey-Bass, 1982) p.177-97.

23. Thomas J. Cottle, College: Reward and Betrayal (Chicago: Univ. of Chicago Pr., 1977), p.64-84.

24. The theme paper of Gresham Riley can be found on p.367-69 of this issue of CERL.

\section{INDEX TO COLLEGE E RESEARCH LIBRARIES}

The Index to Volumes 26 to 40 (1965-1979) of College \& Research Libraries and College and Research Libraries News, prepared by Eldon W. Tamblyn, is available from ACRL. The 63-page index is $\$ 10$ for ACRL members and $\$ 12$ for nonmembers. It is available prepaid from ACRL, 50 E. Huron Street, Chicago, IL 60611. 